Article

\title{
C-Type Natriuretic Peptide (CNP) Inhibition of Interferon- $\gamma$-Mediated Gene Expression in Human Endothelial Cells In Vitro
}

\author{
Amy Day ${ }^{1,2}$, Zoe Jameson ${ }^{1,2}$, Carolyn Hyde ${ }^{3}$, Bigboy Simbi ${ }^{2}$, Robert Fowkes ${ }^{2, *}$ \\ and Charlotte Lawson $1, *$ (D) \\ 1 Cardiovascular and Inflammation Biology Group, Comparative Biomedical Sciences, \\ Royal Veterinary College, Royal College Street London, NW1 0TU, UK; Amy.Day@gstt.nhs.uk (A.D.); \\ zjameson3@rvc.ac.uk (Z.J.) \\ 2 Endocrine Signalling Group, Royal Veterinary College, University of London, Royal College Street, \\ London NW1 0TU, UK; bsimbi@rvc.ac.uk \\ 3 Bio-Analysis Centre, London Bioscience Innovation Centre, Royal College Street, London NW1 0NH, UK; \\ cali@b-ac.co.uk \\ * Correspondence: chlawson@rvc.ac.uk (C.L.); rfowkes@rvc.ac.uk (R.F.); Tel.: +44-(0)20-7468-1216 (C.L.)
}

Received: 30 July 2018; Accepted: 11 September 2018; Published: 14 September 2018

\begin{abstract}
Cardiovascular diseases, including atherosclerosis, now account for more deaths in the Western world than from any other cause. Atherosclerosis has a chronic inflammatory component involving Th1 pro-inflammatory cytokines such as IFN- $\gamma$, which is known to induce endothelial cell inflammatory responses. On the other hand CNP, which acts via its receptors to elevate intracellular cGMP, is produced by endothelium and endocardium and is upregulated in atherosclerosis. It is believed to be protective, however its role in vascular inflammation is not well understood. The aim of this study was to investigate the effects of CNP on human endothelial cell inflammatory responses following IFN- $\gamma$ stimulation. Human umbilical vein endothelial cells were treated with either IFN- $\gamma$ $(10 \mathrm{ng} / \mathrm{mL})$ or CNP $(100 \mathrm{~nm})$, or both in combination, followed by analysis by flow cytometry for expression of MHC class I and ICAM-1. IFN- $\gamma$ significantly increased expression of both molecules, which was significantly inhibited by CNP or the cGMP donor 8-Bromoguanosine $3^{\prime}, 5^{\prime}$-cyclic monophosphate $(1 \mu \mathrm{m})$. CNP also reduced IFN- $\gamma$ mediated kynurenine generation by the IFN- $\gamma$ regulated enzyme indoleamine-2,3-deoxygenase (IDO). We conclude that CNP downmodulates IFN- $\gamma$ induced pro-inflammatory gene expression in human endothelial cells via a cGMP-mediated pathway. Thus, CNP may have a protective role in vascular inflammation and novel therapeutic strategies for CVD based on upregulation of endothelial CNP expression could reduce chronic EC inflammation.
\end{abstract}

Keywords: C-type natriuretic peptide; endothelium; inflammation; cardiovascular; interferon gamma; indoleamine-2,3-dioxygenase

\section{Introduction}

According to the latest statistics published by the American Heart Association cardiovascular disease (CVD) is the largest cause of death worldwide and accounts for over 750,000 deaths in the USA annually [1,2]. The importance of the endothelium is well established for the initial development and subsequent advancement of CVD, having a large influence on maintenance of blood vessel tone via production of nitric oxide and other vasoactive factors. Furthermore, a healthy endothelium is responsible for the maintenance of an anti-thrombotic environment via the production of tissue factor pathway inhibitors and thrombomodulin [3,4]. There is now compelling evidence that chronic systemic 
inflammation also has a major impact on progression of CVD, with accelerated secondary CVD being noted in obese individuals, and as a risk factor for patients with diabetes or autoimmunity [1].

There is very strong evidence that $\mathrm{CD}^{+} \mathrm{T}$ helper type 1 (Th1) cells are present in early atheromatous lesions and contribute to lesion progression [5], including production of the pro-inflammatory cytokine, interferon gamma (IFN- $\gamma$ ). IFN- $\gamma$ has many pro-inflammatory effects on vascular endothelial cells (EC), most notably enhancing the expression of adhesion molecules involved in firm adhesion of both monocytes (VCAM-1), and other leukocyte populations (ICAM-1 [6]). It also increases expression of MHC class I and MHC Class II in human EC [7], which may lead to further activation of antigen specific $\mathrm{CD} 8$ and $\mathrm{CD} 4^{+} \mathrm{T}$ cells, thus contributing to plaque progression.

IFN- $\gamma$ also has a number of immuno-regulatory functions, one of the most well described is its upregulation of indoleamine-2,3-deoxygenase (IDO), an inducible enzyme that reduces tryptophan availability by catalyzing its breakdown to kynurenine for reviews see [8-11]. This reduction in bioavailable tryptophan in the local microenvironment of the inflamed vasculature could potentially reduce the activity of highly metabolic cells such as $\mathrm{T}$ lymphocytes and myeloid cells and therefore reduce the chronic immune response.

Atrial- and B-Type natriuretic peptides (ANP and BNP, respectively) are well characterised hormones that exert profound effects on the cardiovascular system, as well as having established anti-inflammatory roles in the endothelium and other tissues [12-15]. C-type natriuretic peptide (CNP) is a 22 amino acid peptide, the third member of the natriuretic peptide family, identified first in extracts from porcine brain [16]. It is known to have actions on central regulation of vasoactive hormones such as vasopressin and adrenocorticotrophin hormone release, but has also been shown to have direct vasodilatory effects, in particular on smooth muscle relaxation. Coupled with the finding that it is less well expressed in heart than other family members and its abundance in endothelium, it has been hypothesized to be a third, so called, endothelial derived hyperpolarizing factor (EDHF), alongside nitric oxide and prostacyclin $[17,18]$. CNP has also been described to have broadly "anti-inflammatory" effects on endothelial cells in vitro [19-21], to be anti-fibrotic [22-24] and to be cardioprotective [25-28].

We hypothesized that as CNP has been shown to be abundantly expressed in endothelial cells and to have broadly anti-inflammatory effects on EC it can act as a protective brake, specifically acting on pro-inflammatory molecule expression to limit leukocyte emigration and IDO expression to limit subsequent activation after an inflammatory insult. We measured the effect of CNP administration on endothelial pro-inflammatory gene expression including ICAM-1, MHCI, MHCII and IDO activity after treatment of human umbilical vein endothelial cells with IFN- $\gamma$.

\section{Materials and Methods}

\subsection{Materials}

All reagents were from Sigma (Poole, UK) unless otherwise stated. All tissue culture reagents were from Sigma or Gibco (ThermoFisher, Loughborough, UK), and plastics were from Nunc (ThermoFisher; Loughborough, UK).

\subsection{Cell Culture}

Umbilical cords were collected from The Royal London Hospital with approval from the East London Research Ethics Committee and according to the Declaration of Helsinki. Human umbilical vein endothelial cells (HUVEC) were isolated according to a modified method of Jaffe [29] and maintained as described previously [30]. Cells were seeded onto plates pre-coated with gelatin at $2 \times 10^{5}$ cells/well ( 6 well) or $5 \times 10^{4}$ cells/well ( 24 well) plates as appropriate. They were allowed to adhere overnight before treatment with IFN- $\gamma 10 \mathrm{ng} / \mathrm{mL}$ (Insight Biotech, Wembley, UK), $100 \mathrm{~nm}$ CNP (Sigma, Poole, UK) for up to $72 \mathrm{~h}, 1 \mu \mathrm{m}$ 8-bromo-cGMP (Sigma, Poole, UK) or $100 \mu \mathrm{m}$ 8-(4-Chlorophenylthio)-guanosine 3',5'-cyclic monophosphate (8-CPT-cGMP; Sigma, Poole, UK), for $48 \mathrm{~h}$. 


\subsection{Flow Cytometry}

HUVEC were treated on 24 well plates for up to $72 \mathrm{~h}$ as above. The supernatants were removed and snap frozen at $-80{ }^{\circ} \mathrm{C}$ for further analysis. Cells were harvested by trypsinization. Cells were centrifuged and the pellet resuspended in $2 \mathrm{~mL}$ PBS divided between four $5 \mathrm{~mL}$ FACS tubes and re-centrifuged. Pellets were resuspended in $50 \mu \mathrm{L}$ PBS and primary antibodies added at predetermined concentrations (anti-human ICAM-1 clone 6.5B5 (a gift from Professor DO Haskard, Imperial College UK); anti-MHC class I clone W6/32 (ATCC); MHC class II clone L243 (ATCC)). Cells were held on ice for $30 \mathrm{~min}$, washed with $2 \mathrm{~mL}$ ice cold PBS, centrifuged, pellets were resuspended in $50 \mu \mathrm{L}$ cold PBS with predetermined concentration of FITC-conjugated Goat anti-mouse-Ig antibody (Jackson; Stratech Luton, UK) and incubated on ice for $30 \mathrm{~min}$ followed by a wash with $2 \mathrm{~mL}$ ice cold PBS, and centrifugation. Pellets were resuspended in $0.5 \mathrm{~mL} \mathrm{PBS} / 0.5 \%$ formaldehyde and held at $4{ }^{\circ} \mathrm{C}$ before analysis by flow cytometry using a FACS CANTO II with FACS DIVA software (BD Biosciences; Oxford, UK). The flow cytometer was calibrated daily with CS\&T beads (BD Biosciences) according to the manufacturer's instructions. Cell populations were gated on FSC/SSC and using a negative control of FITC-conjugated secondary antibody alone.

\section{4. cGMP Assay}

Cells were treated with CNP in quadruplicate in 24 well plates for $30 \mathrm{~min}$ at $37^{\circ} \mathrm{C}$ before removal of culture medium and lysis and fixation with $750 \mu \mathrm{L} 100 \%$ Ethanol for $5 \mathrm{~min}$ at RT before freezing at $-20^{\circ} \mathrm{C}$ until analysis using cGMP EIA (R\&D, Oxford, UK) according to the manufacturer's instructions.

\subsection{Mass Spectrometry for Tryptophan Metabolites}

Four metabolites of tryptophan were prepared at $1 \mathrm{mg} / \mathrm{mL}$ for use as standards Kynurenine (K), 2,3-Pyridinecarboxylic acid (PCA), 3 Hydroxy DL Kynerenine (HDLK) and 3 Hydroxyanthranilic acid (HAA) (All from Sigma). K, PCA and HAA were dissolved in $500 \mu \mathrm{L}$ of water and $500 \mu \mathrm{L}$ methanol. HDLK was dissolved in $600 \mu \mathrm{L}$ methanol, $400 \mu \mathrm{L}$ water and $1 \mu \mathrm{L}$ formic acid. Standards were; $10 \mu \mathrm{g} / \mathrm{mL}, 100 \mathrm{ng} / \mathrm{mL}$ and $10 \mathrm{ng} / \mathrm{mL}$.

Samples were thawed at room temperature and $10 \mu \mathrm{L}$ of each sample was diluted with $495 \mu \mathrm{L}$ of water and $495 \mu \mathrm{L}$ of methanol.

A Shimadzu LCMS8040 was used-a triple quadruple mass spectrometer with high sensitivity, high speed and high reliability. Analysis of both positive and negative ions is possible in the same experiment due to the ultrafast polarity switching capabilities. LabSolutions software was used for the acquisition and analysis of data. A Phenomenex (Macclesfield, UK) Kinetex PFP $(50 \times 2.1 \mathrm{~mm}$ i.d., $2.6 \mu \mathrm{m}, 100 \AA$ ) with mobile phases A $(0.1 \%$ formic acid in water, $v / v)$ and B $(0.1 \%$ formic acid in Methanol, $v / v$ ) was used. The column was kept at $40{ }^{\circ} \mathrm{C}$. All analytes were detected in positive ion multiple reaction monitoring (MRM) mode. The flow rate, at all times, was $0.25 \mathrm{~mL} / \mathrm{min}$. The column effluent was delivered to the mass spectrometer with no split. If not otherwise noted, an injection volume of $1 \mu \mathrm{L}$ was used. All MS parameters were optimized by the auto optimization program. The ESI source was operated under standard conditions of Nebulising Gas at $3 \mathrm{~L} / \mathrm{min}$, DL temperature at $250{ }^{\circ} \mathrm{C}$, a heat block temperature at $400{ }^{\circ} \mathrm{C}$ and drying gas flow at $15 \mathrm{~L} / \mathrm{min}$.

\subsection{Data Analysis}

Post-acquisition analysis of flow cytometry data was using FACS DIVA II software (BD Biosciences, Oxford, UK), FloJo v10 (FLoJo LLC, Ashland, OR, USA) and Flowing Software v2.5.1 (University of Turku, Finland) and data is presented as fold increase in median fluorescence intensity over untreated cells; mean \pm SEM. All statistical analyses were performed using Prism 7 (GraphPad Software Inc., CA, USA). One-way ANOVA followed by Bonferroni post-test or Independent T tests were used as appropriate, with $p<0.05\left(^{*}\right)$ considered as statistically significant. Mann-Whitney tests were used to 
analyze data that were not normally distributed. All experiments were performed on at least three separate isolates of HUVEC and data are presented as mean \pm SEM.

\section{Results}

\subsection{CNP Reduces IFN- $\gamma$ Mediated Expression of Pro-Inflammatory Molecules on the Surface of HUVEC.}

As shown in Figure 1, and as has been described previously in the literature [31,32] IFN- $\gamma$ induced $4.9 \pm 1.2$-fold increase in ICAM-1 expression above basal levels in HUVEC after $24 \mathrm{~h}$ treatment, increasing to $7.4 \pm 0.9$-fold after $48 \mathrm{~h}$ and maintained for at least $72 \mathrm{~h}$. Alone, CNP had no effect on ICAM-1 cell surface expression; however, it caused a significant reduction in the IFN- $\gamma$ mediated response at both $24 \mathrm{~h}$ (to $2.6 \pm 0.06$-fold, $p<0.05$ ) and $48 \mathrm{~h}$ (to $4.3 \pm 0.7$-fold, $p<0.05$ ) with the trend continuing out to $72 \mathrm{~h}$ treatment ( $3.7 \pm 1.0$-fold, $p=0.24$ ). Similarly, CNP did not affect basal MHC class I expression when administered alone to HUVEC for up to $72 \mathrm{~h}$ (Figure 2) but significantly reduced IFN- $\gamma$ mediated increased surface expression after $48 \mathrm{~h}$ co-treatment $(6.4 \pm 1.2$-fold vs. $3.2 \pm 0.6$-fold, $p<0.05)$ and $72 \mathrm{~h}(7.8 \pm 2.5$-fold vs. $3.3 \pm 0.6$-fold $p<0.05)$. In contrast (Figure 3$)$, although IFN- $\gamma$ increased the expression of MHC class II on the surface of HUVEC at each time-point (2.8 \pm 1.1 -fold, $5.5 \pm 1.4$-fold, $17.2 \pm 6.0$-fold, at $24 \mathrm{~h}, 48 \mathrm{~h}$ and $72 \mathrm{~h}$, respectively), CNP failed to significantly alter these responses.
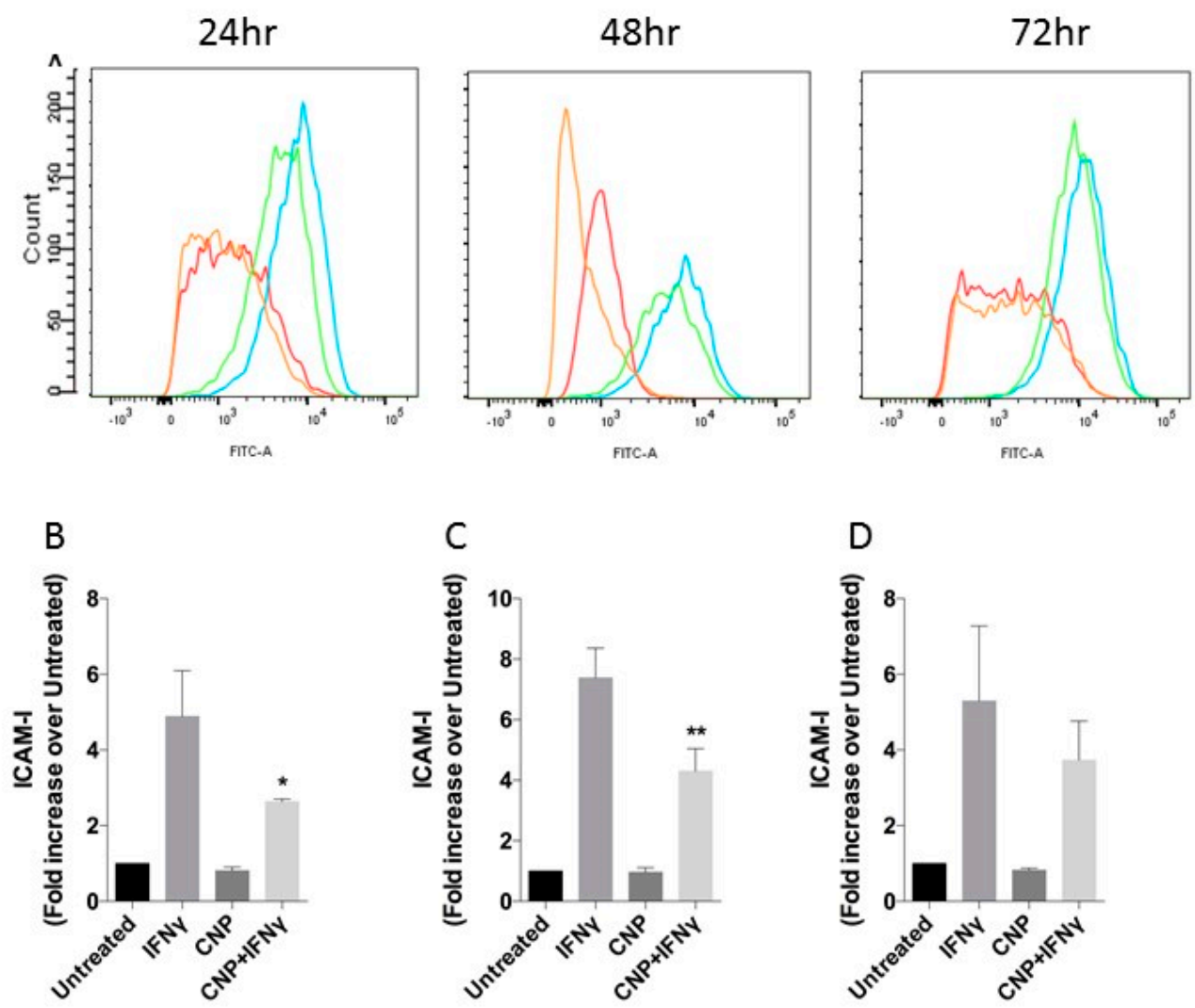

Figure 1. ICAM-1 expression in HUVEC after incubation with IFN- $\gamma$ alone or in combinations with CNP for up to $72 \mathrm{~h}$. (A) Representative flow cytometry histograms for ICAM-1 after incubation of HUVEC alone (Red) or with IFN- $\gamma$ (Blue), CNP (Orange) or IFN- $\gamma$ and CNP (Green) for the indicated times. (B-D) Mean Fluorescence Intensity (expressed as fold increase over MFI of untreated cells, which range from 820 to 3089; mean \pm SEM) for ICAM-1 on untreated HUVEC or after $24 \mathrm{~h}$ (B), $48 \mathrm{~h}$ (C) or $72 \mathrm{~h}(\mathrm{D})$ treatment with IFN- $\gamma$ alone or in combination with CNP; $\mathrm{n}=3$ HUVEC isolates $\left({ }^{*} p<0.05\right.$, ** $p<0.01$, significantly different from IFN- $\gamma$ alone). 

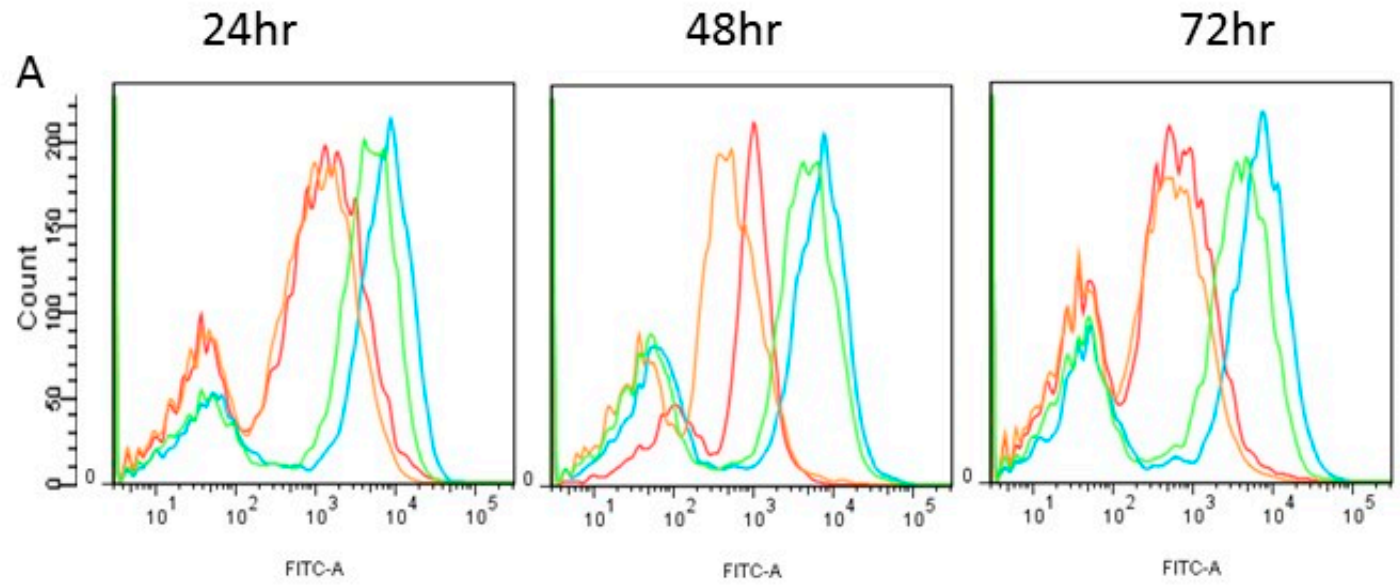

B

C
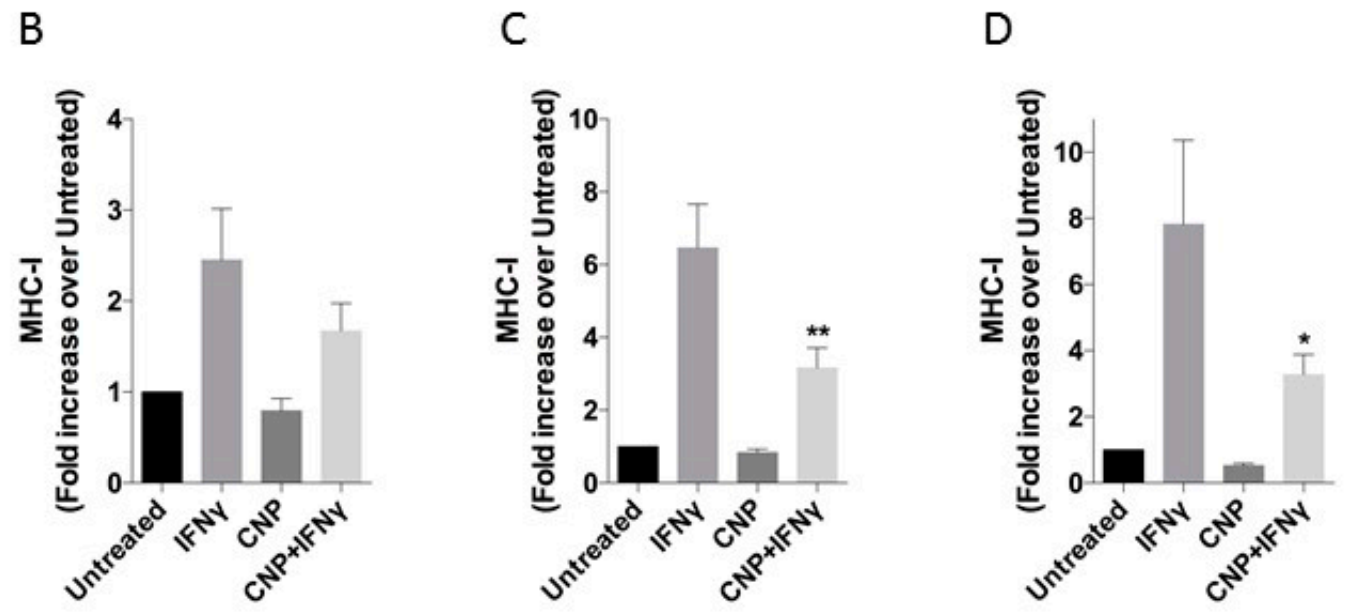

Figure 2. MHC class I expression in HUVEC after incubation with IFN- $\gamma$ alone or in combinations with CNP for up to $72 \mathrm{~h}$. (A) Representative flow cytometry histograms for MHC-I after incubation of HUVEC alone (Red) or with IFN- $\gamma$ (Blue), CNP (Orange) or IFN- $\gamma$ and CNP (Green) for the indicated times. (B-D) Mean Fluorescence Intensity (expressed as fold increase over MFI of untreated cells, which ranged from 2079 to 6549; mean \pm SEM) for MHC-I on untreated HUVEC or after $24 \mathrm{~h}$ (B), $48 \mathrm{~h}(\mathbf{C})$ or $72 \mathrm{~h}(\mathbf{D})$ treatment with IFN- $\gamma$ alone or in combination with CNP; $n=3$ HUVEC isolates ( ${ }^{*} p<0.05,{ }^{* *} p<0.01$, significantly different from IFN- $\gamma$ alone). 


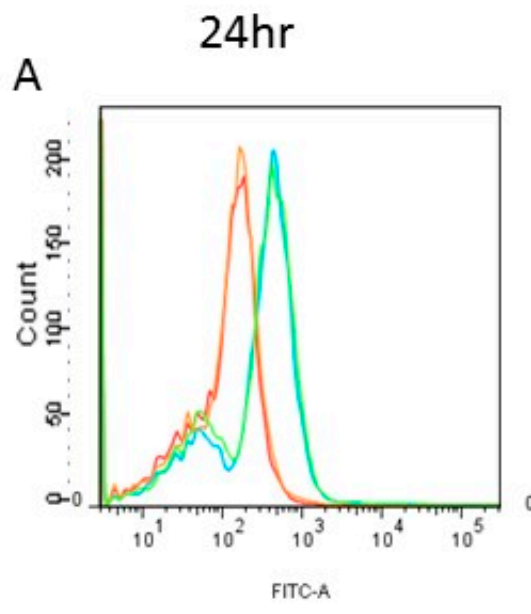

B

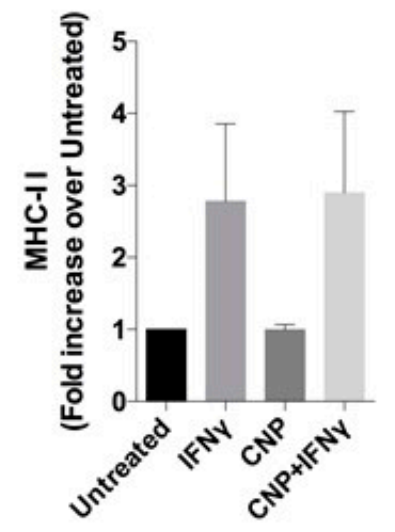

$48 \mathrm{hr}$

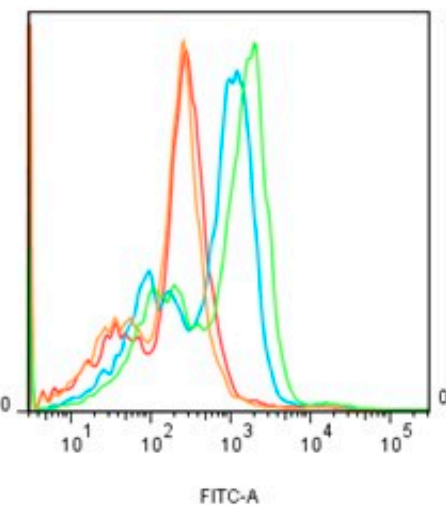

$\mathrm{C}$

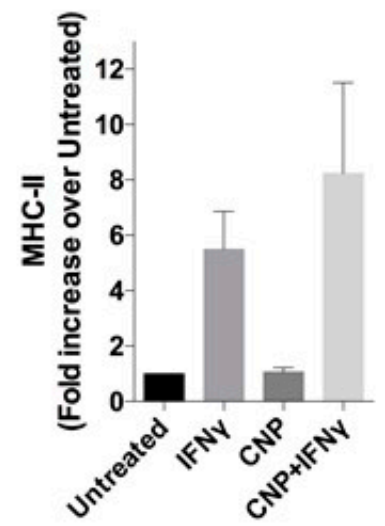

$72 \mathrm{hr}$

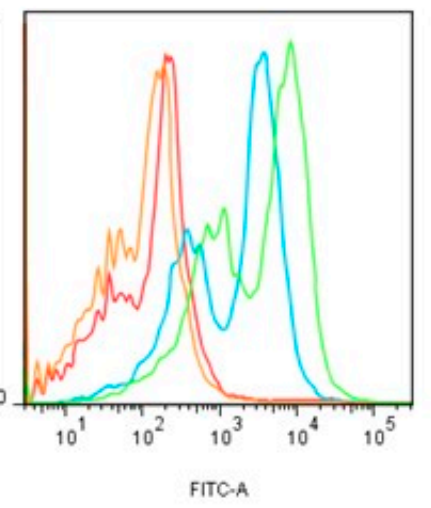

D

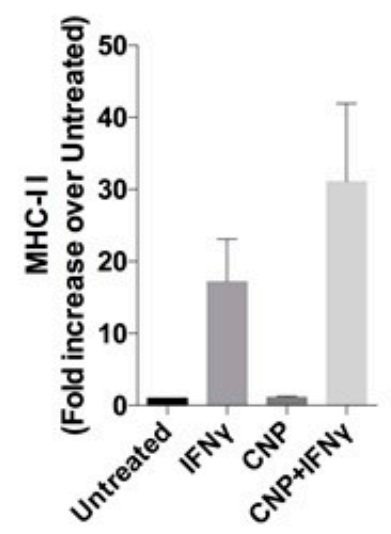

Figure 3. MHC class II expression in HUVEC after incubation with IFN- $\gamma$ alone or in combinations with CNP for up to $72 \mathrm{~h}$. (A) Representative flow cytometry histograms for MHC-II after incubation of HUVEC alone (Red) or with IFN- $\gamma$ (Blue), CNP (Orange) or IFN- $\gamma$ and CNP (Green) for the indicated times. (B-D) Mean Fluorescence Intensity (expressed as fold increase over MFI of untreated cells, which ranged from 187 to 216; mean \pm SEM) for MHC-II on untreated HUVEC or after $24 \mathrm{~h}$ (B), $48 \mathrm{~h}$

(C) or $72 \mathrm{~h}$ (D) treatment with IFN- $\gamma$ alone or in combination with CNP; $n=3$ HUVEC isolates.

\subsection{CNP Induces cGMP Release in HUVEC}

CNP exerts the vast majority of its effects via the guanylyl cyclase B (GC-B) receptor and cGMP generation [33,34]. We therefore measured cGMP accumulation in HUVEC stimulated with 0 or $100 \mathrm{~nm}$ CNP in the presence of $1 \mathrm{~mm}$ IBMX. As shown (Figure 4A), CNP stimulated total cGMP accumulation in HUVEC isolates, to $2.5 \pm 0.3$-fold above basal $\left({ }^{*} p=0.015\right)$. To determine whether the observed effects of CNP on IFN- $\gamma$-induced ICAM- 1 and MHC class I expression in HUVEC were mediated via cGMP, we used a cell permeable cGMP agonist (8-Br-cGMP) to mimic the observed cGMP increase in response to CNP. As shown (Figure 4B,C), $1 \mathrm{~mm} 8$-Br-cGMP caused an identical inhibition of the IFN- $\gamma$-mediated increases in ICAM-1 (7.6 \pm 1.04 -fold vs. $2.4 \pm 0.4$-fold, $p<0.001)$ and MHC class I expression ( $6.6 \pm 0.8$-fold vs. $2.5 \pm 0.5$-fold, $p<0.001)$. However, similar to CNP, 8 -Br-cGMP failed to alter the effects of IFN- $\gamma$ on MHC class II expression (Figure 4D). 8-CPT-cGMP also reduced IFN- $\gamma$ mediated increase in MHC class I (Supplementary Figure S1). Collectively, these data support a role for GC-B/cGMP signaling in attenuating the effects of IFN- $\gamma$ in HUVEC. 

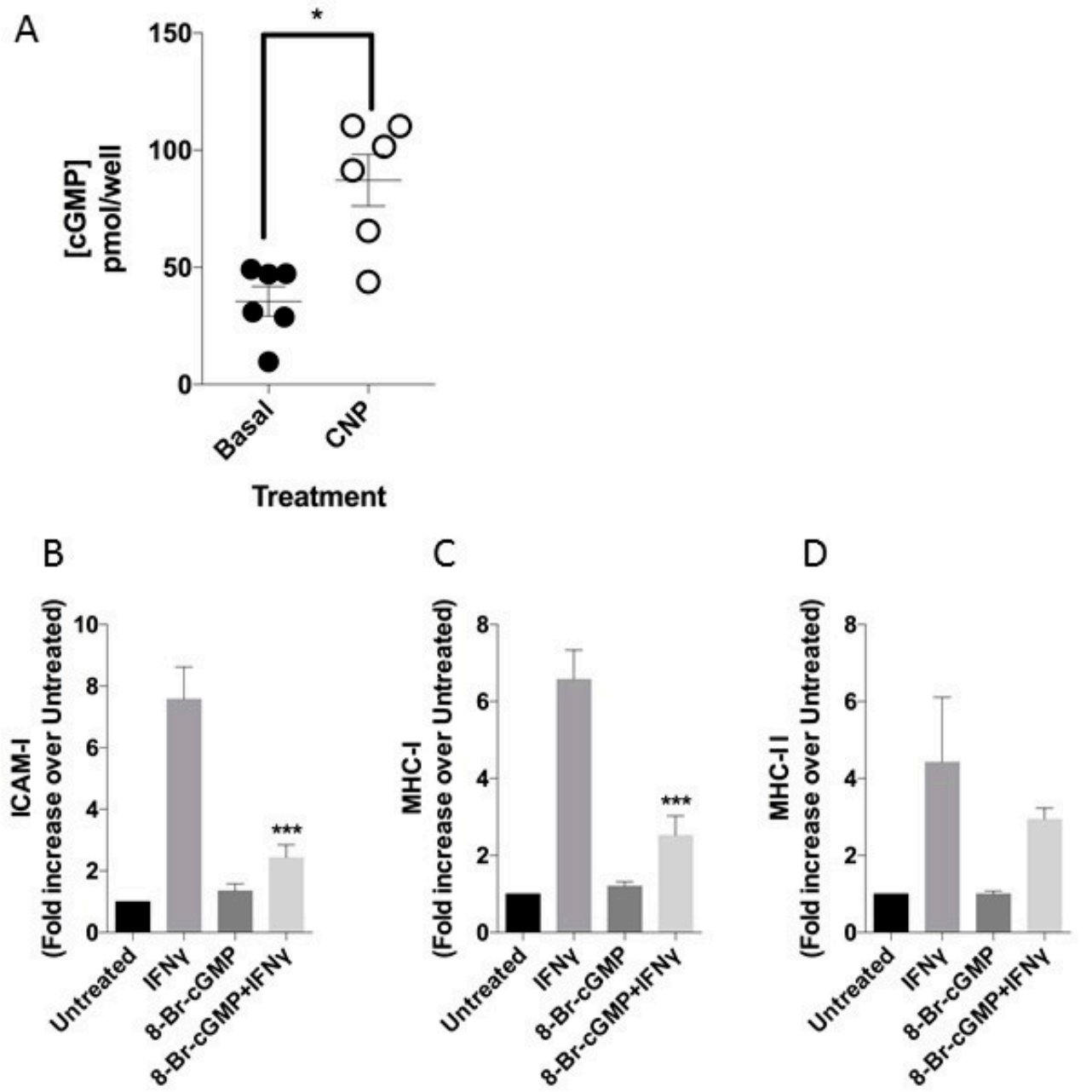

Figure 4. cGMP mediated effects on cell surface receptor expression in HUVEC. (A) CNP-stimulated cGMP accumulation in HUVEC isolates, after $30 \mathrm{~min}$ stimulation with $100 \mathrm{~nm}$ CNP in the presence of 1 mm IBMX. Data shown are means \pm SEM pooled from 6 independent isolates $(n=6)$, each performed in duplicate ( ${ }^{*} p=0.015$, significantly different from Basal). (B-D) Effect of 8-bromo-cGMP on IFN- $\gamma$ mediated ICAM-1 (B), MHC-I (C), and MHC-II (D) expressed as fold increase over MFI of untreated cells expression after 48hr treatment (which ranged from 572 to 819, 1313 to 2012, 176 to 230, for ICAM-1, MHC-I and MHC-II, respectively). $n=3$ HUVEC isolates $\left({ }^{*} p<0.05,{ }^{* * *} p<0.001\right.$, significantly different from IFN- $\gamma$ alone).

\subsection{CNP Inhibits IFN- $\gamma$ Induced Upregulation of Tryptophan Metabolism}

IFN- $\gamma$ has previously been shown to upregulate expression of indolamine 2,3-dioxygenase (IDO), an inducible enzyme found at sites of immune privilege and thought to be important for exerting the anti-microbial effects of IFN- $\gamma$ [11]. The enzyme works to reduce tryptophan availability, catalyzing the first step of the pathway to kynurenine, which can be measured by mass spectrometry in vivo in plasma or in vitro in cell culture medium. As shown in Figure 5, IFN- $\gamma$ stimulation induced a significant increase in kynurenine in the culture supernatant and this was significantly reduced by co-treatment with CNP after $48 \mathrm{~h}(100.0 \pm 5.3 \%$ vs. $24.5 \pm 2.4 \%, p<0.01)$. This suggests that as well as potentially downregulating leukocyte adhesion and trans-endothelial migration during endothelial inflammation it may have an opposing effect of maintaining function of those leukocytes which are able to adhere and migrate at inflammatory sites in the vasculature. 
A

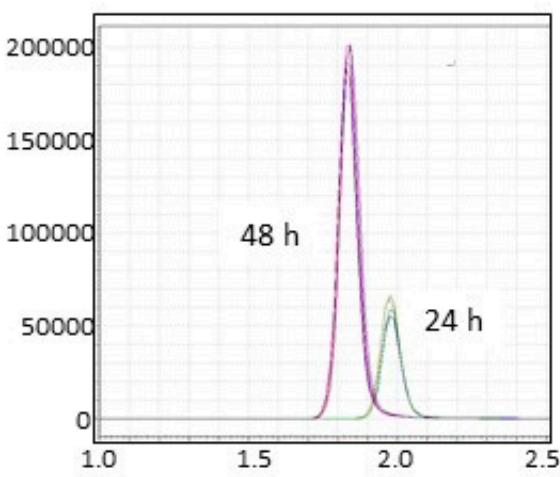

B

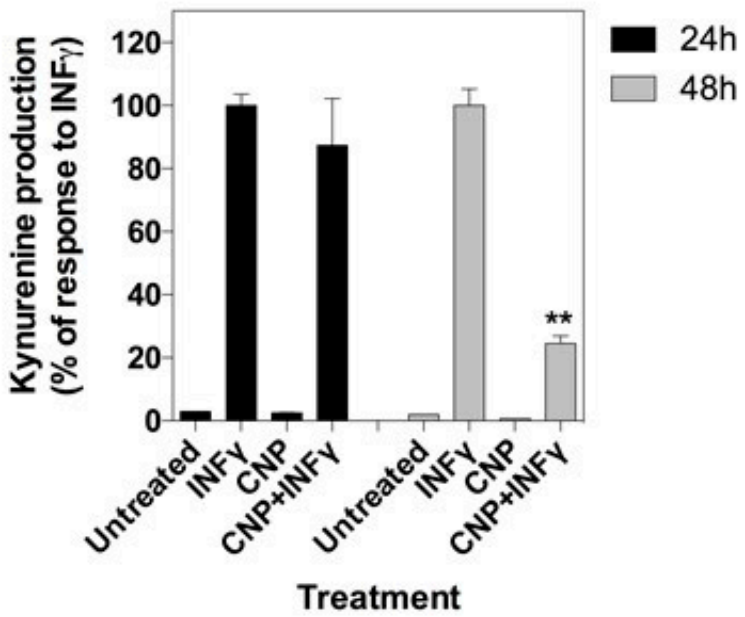

Figure 5. CNP downregulates IFN- $\gamma$-mediated tryptophan metabolism in HUVEC. (A) Representative chromatogram of kynurenine production following IFN- $\gamma$ treatment. (B) Kynurenine production from untreated HUVEC or after $24 \mathrm{~h}$ and $48 \mathrm{~h}$ treatment with IFN- $\gamma$ alone or in combination with CNP. Data shown are representative from a single HUVEC isolate, expressed as \% IFN- $\gamma$-stimulated kyunurenine production), and performed in duplicate. ${ }^{* *} p<0.01$, significantly different from IFN- $\gamma$ alone).

\section{Discussion}

Here, we have shown that $\mathrm{CNP}$, a natriuretic peptide shown to be broadly cardioprotective [35] and known to be highly expressed by the endothelium [36] is able to downregulate IFN- $\gamma$-mediated gene expression in human endothelial cells in vitro. In particular, we have shown that CNP significantly inhibited the IFN- $\gamma$ increase in ICAM-1 expression on the cell surface of HUVEC. ICAM- 1 is an adhesion molecule involved in firm adhesion and trans-endothelial migration of leukocytes including neutrophils, monocytes and both $\mathrm{T}$ and $\mathrm{B}$ cells, and is also important for immunological synapse formation during $\mathrm{T}$ cell activation (for review see [37]), so by downregulating expression to basal levels CNP may prevent leukocyte accumulation during vascular inflammation, that could lead to the early stages of fatty streak formation. Likewise, by reducing ICAM-1 expression on the endothelium, immunological synapse formation will be compromised which could limit $\mathrm{T}$ cell accumulation. Thus, development of the pro-inflammatory environment leading to lesion formation will be reduced by some degree. ICAM- 1 is a ligand for $\beta-2$ integrin family members, including $\alpha \mathrm{x} / \beta 2$ (CD11c/CD18), the $\alpha$-subunit (CD11c) having recently been shown to be upregulated in $\mathrm{IDO} / A p o E^{-/-}$mice [38]. However, VCAM-1 has been shown to be an alternative ligand for CD11c [39], which Polyzos et al. [40] recently demonstrated was upregulated in $A p o E^{-/-}$mice and aortic endothelial cells treated chronically with 1-MT to inhibit IDO. Polyzos et al. [40] also showed that CCL2 was increased. Taken together these could explain the increased macrophage accumulation after IDO blockade in these two animal models. Interestingly, CNP has previously been shown to downregulate secretion of CCL2 from THP-1 human macrophage cell line in vitro [41] and there are differences in expression patterns of VCAM-1 in murine and human endothelial cells [7,42]. Future work should examine the effect of $\mathrm{CNP}$ on other IFN $\gamma$-mediated responses including expression of VCAM-1 and CCL2, or the effects of CNP on leukocyte adhesion and trans-endothelial migration.

We have also demonstrated that CNP reduced IFN- $\gamma$-mediated increases in MHC I expression. This could additionally contribute to a brake on $\mathrm{CD}^{+} \mathrm{T}$ cell immune responses in the inflamed environment. Cytotoxic T cells have been identified in advanced atherosclerotic lesions and may contribute up to $50 \%$ of the lymphocyte population [43]. Activated $\mathrm{CD} 8^{+} \mathrm{T}$ cells have been shown to efficiently migrate into the intima of both healthy and diseased arteries in vitro [43]. Interestingly, 
we did not see an effect of CNP on IFN- $\gamma$ induced MHC class II expression, suggesting that CNP exerts a selective inhibition of CD8 $\mathrm{T}$ cell/NK cell accumulation, whilst allowing CD4 ${ }^{+} \mathrm{T}$ cell activity. There is evidence that certain subsets of $\mathrm{CD}^{+} \mathrm{T}$ cells (Th2-like, Treg) may be beneficial in reducing atherosclerotic lesion formation [3], thus it could be argued that a selective reduction in CD8 vs. CD4 T cell accumulation via CNP's reduction in gene expression mediated by IFN- $\gamma$ is an early protective response by the endothelium.

CNP exerts the vast majority of its effects via the GC-B receptor, and the generation of cGMP [33,34]. In our current study, not only did we confirm the presence of functional GC-B receptors in HUVEC, as described previously [44], but were able to mimic the dampening effects of CNP on IFN- $\gamma$ responsiveness by using the cell permeable analogue, 8-Br-cGMP and with an additional cGMP analogue 8-CPT-cGMP, which is a more membrane permeant molecule. Interestingly, 8-CPT-cGMP only partially recapitulated the effects on MHC-I and ICAM-I seen in the presence of either CNP or 8-Br-cGMP. It is unclear as to why 8-CPT-cGMP failed to inhibit INF-y-stimulated ICAM-1 expression in HUVECs. However, previous studies suggest that the sub-cellular localisation of cGMP generation in cardiomyocytes and HUVEC can influence biological responsiveness $[44,45]$. Therefore, it is possible that CNP, 8-Br-cGMP and 8-CPT-cGMP treatments lead to spatially distinct increases in cGMP within HUVECs that may alter endothelial cell responsiveness.

HUVEC also express the NPR-C receptor, which has been strongly implicated in the role that CNP performs to maintain vascular homeostasis [46]. Even though NPR-C lacks intrinsic guanylyl cyclase and, therefore, does not directly enhance cGMP production, previous studies have shown that activation of NPR-C by natriuretic peptides may also stimulate nitric oxide production, leading to cGMP generation via soluble guanylyl cyclase [47]. Therefore, although our data implicate GC-B/cGMP signaling as a mechanism for the anti-inflammatory effects of CNP in HUVEC, it is perfectly conceivable that additional, NPR-C-mediated mechanisms may also contribute to these effects.

We have used HUVEC as model human endothelial cells in this study because umbilical cords are a readily available, ethically uncontroversial source of human vascularized tissue. HUVEC have been used for more than 40 years and their responses to a range of stimuli including IFN- $\gamma$ are very well characterized and have been shown to be comparable to adult human large artery endothelium [48].

In conclusion, CNP is able to downregulate IFN- $\gamma$-mediated gene expression in the endothelium, which could limit vascular inflammation by directing specific $\mathrm{T}$ cell subsets into developing atherosclerotic lesions, ultimately affecting atheroma progression. Further work is required to determine whether modulation of endogenously expressed endothelial CNP or addition of exogenous CNP is of potential therapeutic value to treat atherosclerosis in vivo.

Supplementary Materials: The following are available online at http:/ / www.mdpi.com/2079-6374/8/3/86/s1, Figure S1: ICAM-1 and MHC Class I expression in HUVEC after incubation with IFN- $\gamma$ alone or in combinations with 8-CPT cGMP for $48 \mathrm{~h}$.

Author Contributions: Conceptualization C.L., R.F.; experimental data and analysis A.D., Z.J., C.H., B.S., C.L., R.F.; preparation of the manuscript C.L., R.F.

Funding: BBSRC Project grant BBD0015601 awarded to RCF.

Conflicts of Interest: The authors declare no conflict of interest.

\section{References}

1. Mozaffarian, D.; Benjamin, E.J.; Go, A.S.; Arnett, D.K.; Blaha, M.J.; Cushman, M.D.; Das, S.R.; De Ferranti, S.; Cushman, M.; Despr's, J.P.; et al. Executive Summary: Heart Disease and Stroke Statistics-2016 Update: A Report From the American Heart Association. Circulation 2016, 133, 447-454. [CrossRef] [PubMed]

2. Benjamin, E.J.; Virani, S.S.; Callaway, C.W.; Chamberlain, A.M.; Chang, A.R.; Cheng, S.; Chiuve, S.E.; Cushman, M.; Delling, F.N.; Deo, R. Heart Disease and Stroke Statistics-2018 Update: A Report From the American Heart Association. Circulation 2018, 137, e67-e492. [CrossRef] [PubMed] 
3. Hansson, G.K.; Libby, P.; Tabas, I. Inflammation and plaque vulnerability. J. Intern. Med. 2015, $278,483-493$. [CrossRef] [PubMed]

4. Martin, F.A.; Murphy, R.P.; Cummins, P.M. Thrombomodulin and the vascular endothelium: Insights into functional, regulatory, and therapeutic aspects. Am. J. Physiol. Heart Circ. Physiol. 2013, 304, H1585-H1597. [CrossRef] [PubMed]

5. Ketelhuth, D.F.; Hansson, G.K. Cellular immunity, low-density lipoprotein and atherosclerosis: Break of tolerance in the artery wall. Thromb. Haemost. 2011, 106, 779-786. [CrossRef] [PubMed]

6. Thornhill, M.H.; Wellicome, S.M.; Mahiouz, D.L.; Lanchbury, J.S.S.; Kyan-Aung, U.; Haskard, D.O. Tumor necrosis factor combines with IL-4 or IFN-gamma to selectively enhance endothelial cell adhesiveness for T cells. The contribution of vascular cell adhesion molecule-1-dependent and -independent binding mechanisms. J. Immunol. 1991, 146, 592-598. [PubMed]

7. Lidington, E.A.; Moyes, D.L.; McCormack, A.M.; Rose, M.L. A comparison of primary endothelial cells and endothelial cell lines for studies of immune interactions. Transpl. Immunol. 1999, 7, 239-246. [CrossRef]

8. Mbongue, J.C.; Nicholas, D.A.; Torrez, T.W.; Kim, N.-S.; Firek, A.F.; Langridge, W.H.R. The Role of Indoleamine 2,3-Dioxygenase in Immune Suppression and Autoimmunity. Vaccines 2015, 3, 703-729. [CrossRef] [PubMed]

9. Mellor, A.L.; Keskin, D.B.; Johnson, T.; Chandler, P.; Munn, D.H. Cells expressing indoleamine 2,3-dioxygenase inhibit T cell responses. J. Immunol. 2002, 168, 3771-3776. [CrossRef] [PubMed]

10. Mellor, A.L.; Munn, D.H. Tryptophan catabolism and T-cell tolerance: Immunosuppression by starvation? Immunol. Today 1999, 20, 469-473. [CrossRef]

11. Taylor, M.W.; Feng, G.S. Relationship between interferon-gamma, indoleamine 2,3-dioxygenase, and tryptophan catabolism. FASEB J. 1991, 5, 2516-2522. [CrossRef] [PubMed]

12. Curry, F.-R.E.; Clark, J.F.; Jiang, Y.; Kim, M.-H.; Adamson, R.H.; Simon, S.I. The role of atrial natriuretic peptide to attenuate inflammation in a mouse skin wound and individually perfused rat mesenteric microvessels. Physiol. Rep. 2016, 4, e12968. [CrossRef] [PubMed]

13. Khoury, E.E.; Kinaneh, S.; Aronson, D.; Amir, O.; Ghanim, D.; Volinsky, N.; Azzam, Z.; Abassi, Z. Natriuretic peptides system in the pulmonary tissue of rats with heart failure: Potential involvement in lung edema and inflammation. Oncotarget 2018, 9, 21715-21730. [CrossRef] [PubMed]

14. Kuhn, M. Endothelial actions of atrial and B-type natriuretic peptides. Br. J. Pharmacol. 2012, 166, $522-531$. [CrossRef] [PubMed]

15. Okamoto, A.; Nojiri, T.; Konishi, K.; Tokudome, T.; Miura, K.; Hosoda, H.; Hino, J.; Miyazato, M.; Kyomoto, Y.; Asai, K. Atrial natriuretic peptide protects against bleomycin-induced pulmonary fibrosis via vascular endothelial cells in mice: ANP for pulmonary fibrosis. Respir. Res. 2017, 18, 1. [CrossRef] [PubMed]

16. Sudoh, T.; Minamino, N.; Kangawa, K.; Matsuo, H. C-type natriuretic peptide (CNP): A new member of natriuretic peptide family identified in porcine brain. Biochem. Biophys. Res. Commun. 1990, 168, 863-870. [CrossRef]

17. Ahluwalia, A.; Hobbs, A.J. Endothelium-derived C-type natriuretic peptide: More than just a hyperpolarizing factor. Trends Pharmacol. Sci. 2005, 26, 162-167. [CrossRef] [PubMed]

18. Scotland, R.S.; Ahluwalia, A.; Hobbs, A.J. C-type natriuretic peptide in vascular physiology and disease. Pharmacol. Ther. 2005, 105, 85-93. [CrossRef] [PubMed]

19. Izumiya, Y.; Araki, S.; Usuku, H.; Rokutanda, T.; Hanatani, S.; Ogawa, H. Chronic C-Type Natriuretic Peptide Infusion Attenuates Angiotensin II-Induced Myocardial Superoxide Production and Cardiac Remodeling. Int. J. Vasc. Med. 2012, 2012, 246058. [CrossRef] [PubMed]

20. Scotland, R.S.; Cohen, M.; Foster, P.; Lovell, M.; Mathur, A.; Ahluwalia, A.; Hobbs, A.J. C-type natriuretic peptide inhibits leukocyte recruitment and platelet-leukocyte interactions via suppression of P-selectin expression. Proc. Natl. Acad. Sci. USA 2005, 102, 14452-14457. [CrossRef] [PubMed]

21. Qian, J.; Haruno, A.; Asada, Y.; Nishida, T.; Saito, Y.; Matsuda, T.; Ueno, H. Local expression of C-type natriuretic peptide suppresses inflammation, eliminates shear stress-induced thrombosis, and prevents neointima formation through enhanced nitric oxide production in rabbit injured carotid arteries. Circ. Res. 2002, 91, 1063-1069. [CrossRef] [PubMed]

22. Hu, P.; Wang, J.; Hu, B.; Lu, L.; Xuan, Q.; Qin, Y. Increased urinary C-type natriuretic peptide excretion may be an early marker of renal tubulointerstitial fibrosis. Peptides 2012, 37, 98-105. [CrossRef] [PubMed] 
23. Li, Z.; Liu, Y.; Li, G.; Li, B.; Liu, Y.; Li, X.; Liu, A. Inhibitory effects of C-type natriuretic peptide on the differentiation of cardiac fibroblasts, and secretion of monocyte chemoattractant protein-1 and plasminogen activator inhibitor-1. Mol. Med. Rep. 2015, 11, 159-165. [CrossRef] [PubMed]

24. Ichiki, T.; Boerrigter, G.; Huntley, B.K.; Sangaralingham, S.J.; McKie, P.M.; Harty, G.J.; Harders, G.E.; Burnett, J.C., Jr. Differential expression of the pro-natriuretic peptide convertases corin and furin in experimental heart failure and atrial fibrosis. Am. J. Physiol. Regul. Integr. Comp. Physiol. 2013, 304, R102-R109. [CrossRef] [PubMed]

25. Burley, D.S.; Hamid, S.A.; Baxter, G.F. Cardioprotective actions of peptide hormones in myocardial ischemia. Heart Fail. Rev. 2007, 12, 279-291. [CrossRef] [PubMed]

26. Soeki, T.; Kishimoto, I.; Okumura, H.; Tokudome, T.; Horio, T.; Mori, K.; Kangawa, K. C-type natriuretic peptide, a novel antifibrotic and antihypertrophic agent, prevents cardiac remodeling after myocardial infarction. J. Am. Coll Cardiol. 2005, 45, 608-616. [CrossRef] [PubMed]

27. Ichiki, T.; Schirger, J.A.; Huntley, B.K.; Brozovich, F.V.; Maleszewski, J.J.; Sandberg, S.M.; Sangaralingham, S.J.; Park, S.J.; Burnett, J.C., Jr. Cardiac fibrosis in end-stage human heart failure and the cardiac natriuretic peptide guanylyl cyclase system: Regulation and therapeutic implications. J. Mol. Cell Cardiol. 2014, 75, 199-205. [CrossRef] [PubMed]

28. Sangaralingham, S.J.; McKie, P.M.; Ichiki, T.; Scott, C.G.; Heublein, D.M.; Chen, H.H.; Bailey, K.R.; Redfield, M.M.; Rodeheffer, R.J.; Burnett, J.C., Jr. Circulating C-type natriuretic peptide and its relationship to cardiovascular disease in the general population. Hypertension 2015, 65, 1187-1194. [CrossRef] [PubMed]

29. Jaffe, E.A.; Nachman, R.L.; Becker, C.G.; Minick, C.R. Culture of human endothelial cells derived from umbilical veins. Identification by morphologic and immunologic criteria. J. Clin. Investing 1973, 52, 2745-2756. [CrossRef] [PubMed]

30. Lawson, C.; Ainsworth, M.; Yacoub, M.; Rose, M. Ligation of ICAM-1 on endothelial cells leads to expression of VCAM-1 via a nuclear factor-kappaB-independent mechanism. J. Immunol. 1999, 162, 2990-2996. [PubMed]

31. Pober, J.S.; Gimbrone, M.A.; Lapierre, L.A.; Mendrick, D.; Fiers, W.; Rothlein, R.; Springer, T. A Overlapping patterns of activation of human endothelial cells by interleukin 1, tumor necrosis factor, and immune interferon. J. Immunol. 1986, 137, 1893-1896. [PubMed]

32. Thornhill, M.H.; Haskard, D.O. IL-4 regulates endothelial cell activation by IL-1, tumor necrosis factor, or IFN-gamma. J. Immunol. 1990, 145, 865-872. [PubMed]

33. Del Ry, S. C-type natriuretic peptide: A new cardiac mediator. Peptides 2013, 40, 93-98. [CrossRef] [PubMed]

34. Potter, L.R. Regulation and therapeutic targeting of peptide-activated receptor guanylyl cyclases. Pharmacol. Ther. 2011, 130, 71-82. [CrossRef] [PubMed]

35. Hobbs, A.; Foster, P.; Prescott, C.; Scotland, R.; Ahluwalia, A. Natriuretic peptide receptor-C regulates coronary blood flow and prevents myocardial ischemia/reperfusion injury: Novel cardioprotective role for endothelium-derived C-type natriuretic peptide. Circulation 2004, 110, 1231-1235. [CrossRef] [PubMed]

36. Chauhan, S.D.; Nilsson, H.; Ahluwalia, A.; Hobbs, A.J. Release of C-type natriuretic peptide accounts for the biological activity of endothelium-derived hyperpolarizing factor. Proc. Natl. Acad. Sci. USA 2003, 100, 1426-1431. [CrossRef] [PubMed]

37. Lawson, C.; Wolf, S. ICAM-1 signaling in endothelial cells. Pharmacol. Rep. 2009, 61, 22-32. [CrossRef]

38. Cole, J.E.; Astola, N.; Cribbs, A.P.; Goddard, M.E.; Park, I.; Green, P.; Davies, A.H.; Williams, R.O.; Feldmann, M.; Monaco, C. Indoleamine 2,3-dioxygenase-1 is protective in atherosclerosis and its metabolites provide new opportunities for drug development. Proc. Natl. Acad. Sci. USA 2015, 112, 13033-13038. [CrossRef] [PubMed]

39. Sadhu, C.; Ting, H.J.; Lipsky, B.; Hensley, K.; Garcia-Martinez, L.F.; Simon, S.I.; Staunton, D.E. CD11c/CD18: Novel ligands and a role in delayed-type hypersensitivity. J. Leukoc. Biol. 2007, 81, 1395-1403. [CrossRef] [PubMed]

40. Polyzos, K.A.; Ovchinnikova, O.; Berg, M.; Baumgartner, R.; Agardh, H.; Pirault, J.; Gister, A.; Assinger, A.; Laguna-Fernandez, A.; Back, M. Inhibition of indoleamine 2,3-dioxygenase promotes vascular inflammation and increases atherosclerosis in Apoe ${ }^{-/-}$mice. Cardiovasc. Res. 2015, 106, 295-302. [CrossRef] [PubMed]

41. Osawa, H.; Yamabe, H.; Kaizuka, M.; Tamura, N.; Tsunoda, S.; Baba, Y.; Shirato, K.; Tateyama, F.; Okumura, K. C-Type natriuretic peptide inhibits proliferation and monocyte chemoattractant protein-1 secretion in cultured human mesangial cells. Nephron 2000, 86, 467-472. [CrossRef] [PubMed] 
42. Dansky, H.M.; Barlow, C.B.; Lominska, C.; Sikes, J.L.; Kao, C.; Weinsaft, J.; Cybulsky, M.I.; Smith, J.D. Adhesion of monocytes to arterial endothelium and initiation of atherosclerosis are critically dependent on vascular cell adhesion molecule-1 gene dosage. Arterioscler. Thromb. Vasc. Biol. 2001, 21, 1662-1667. [CrossRef] [PubMed]

43. Gewaltig, J.; Kummer, M.; Koella, C.; Cathomas, G.; Biedermann, B.C. Requirements for CD8 T-cell migration into the human arterial wall. Hum. Pathol. 2008, 39, 1756-1762. [CrossRef] [PubMed]

44. Rautureau, Y.; Gowers, I.; Wheeler-Jones, C.P.D.; Baxter, G.F. C-type natriuretic peptide regulation of guanosine- $3^{\prime}, 5^{\prime}$-cyclic monophosphate production in human endothelial cells. Auton. Autacoid Pharmacol. 2010, 30, 185-192. [CrossRef] [PubMed]

45. Subramanian, H.; Froese, A.; Jonsson, P.; Schmidt, H.; Gorelik, J.; Nikolaev, V.O. Distinct submembrane localisation compartmentalises cardiac NPR1 and NPR2 signalling to cGMP. Nat. Commun. 2018, 9, 2446. [CrossRef] [PubMed]

46. Moyes, A.J.; Khambata, R.S.; Villar, I.; Bubb, K.J.; Baliga, R.S.; Lumsden, N.G.; Xiao, F.; Gane, P.J.; Rebstock, A.-S.; Worthington, R.J.; et al. Endothelial C-type natriuretic peptide maintains vascular homeostasis. J. Clin. Investing 2014, 124, 4039-4051. [CrossRef] [PubMed]

47. Costa, M.A.; Elesgaray, R.; Balaszczuk, A.M.; Arranz, C. Role of NPR-C natriuretic receptor in nitric oxide system activation induced by atrial natriuretic peptide. Regul. Pept. 2006, 135, 63-68. [CrossRef] [PubMed]

48. Mcdouall, R.M.; Batten, P.; Mccormack, A.; Yacoub, M.H.; Rose, M.L. MHC class II expression on human heart microvascular endothelial cells: Exquisite sensitivity to interferon-gamma and natural killer cells. Transplantation 1997, 64, 1175-1180. [CrossRef] [PubMed]

(C) 2018 by the authors. Licensee MDPI, Basel, Switzerland. This article is an open access article distributed under the terms and conditions of the Creative Commons Attribution (CC BY) license (http:// creativecommons.org/licenses/by/4.0/). 